1975

\title{
Archaeological Investigations at Four Sites in the Dry Comal Watershed Comal County, South Central Texas
}

Thomas C. Kelly

Thomas R. Hester

Center for Archaeological Research

Follow this and additional works at: https://scholarworks.sfasu.edu/ita

Part of the American Material Culture Commons, Archaeological Anthropology Commons, Environmental Studies Commons, Other American Studies Commons, Other Arts and Humanities Commons, Other History of Art, Architecture, and Archaeology Commons, and the United States History Commons

Tell us how this article helped you.

This Article is brought to you for free and open access by the Center for Regional Heritage Research at SFA ScholarWorks. It has been accepted for inclusion in Index of Texas Archaeology: Open Access Gray Literature from the Lone Star State by an authorized editor of SFA ScholarWorks. For more information, please contact cdsscholarworks@sfasu.edu. 


\section{Archaeological Investigations at Four Sites in the Dry Comal Watershed Comal County, South Central Texas}

\section{Creative Commons License}

\section{(c) (1) (8)}

This work is licensed under a Creative Commons Attribution-NonCommercial 4.0 International License 


\title{
Archaeological Investigations at Four Sites \\ in the Dry Comal Watershed \\ Comal County, South Central Texas
}

\author{
Thomas C. Kelly \\ and \\ Thomas R. Hester
}

\section{Center for Archaeological Research \\ The University of Texas at San Antonio Archaeological Survey Report, No. 15 \\ 1975}

UTSA-Center for.

Archaeological Rescarch 
Archaeological Investigations at Four Sites

In the Dry Comal Watershed Comal County, South Central Texas

\author{
Thomas C. Kelly \\ and
}

Thomas R. Hester

Center for Archaeological Research The University of Texas at San Antonio Archaeological Survey Report, No. 15 
TABLE OF CONTENTS

$\begin{array}{lr}\text { Introduction } & \text { Page } \\ \text { The Survey } & 1 \\ \text { Terminology } & 1 \\ \text { Results of the Investigations } & 3 \\ \text { Observations on the Lithics from } & 5 \\ \text { the Sites } & 10 \\ \text { Summary and Recommendations } & 14 \\ \text { Addendum } & 17 \\ \text { References Cited } & 21\end{array}$




\section{FIGURES}

\section{Page}

1. Locations of Archaeological sites in the Vicinity of Floodwater Retarding Structure No. 1, West Fork, Dry Comal Creek.

2. Sites $41 \mathrm{CM} 84,85$ and 86, Floodwater Retarding Structure No. 1 s Conal County, Texas.

3. Views of Site $41 \mathrm{CM} 85$.

4. Views of Sites $41 \mathrm{CM} 86$ and $41 \mathrm{CM} 89$.

5. Lithics from sites $41 \mathrm{CM} 85$ and $41 \mathrm{CM} 86$. 11

6. Lithics from Site $41 \mathrm{CM} 89$.

\section{TABLES}

1. $41 \mathrm{CM} 84,41 \mathrm{CM} 85$ : Excavated Collections

2. 41 CM 86 Controlled Surface Collection

3. Comparisons of Flake Categories at Several South-Central and Central Texas Sites 


\section{INTRODUCTION}

In September, 1975, personnel of The University of Texas at San Antonio, Center for Archaeological Research, conducted an intensive archaeological survey of certain prehistoric sites in the vicinity of Floodwater Retarding Structure No. 1, Dry Comal Creek, Comal County, Texas. These Investigations were carried out at the request of the U.S.D.A. Soil Conservation Service (purchase order 207-Tx-SCS-76).

The area incorporated by Floodwater Retarding Structure No. 1 is on the West Fork of Dry Comal Creek and had been the scene of two earlier archaeological surveys, in November, 1974 (Hester, Bass and Kelly 1975), and in April, 1975 (Kelly and Hester 1975). Both surveys had produced data on a series of archaeological sites (a total of 25 sites was documented: Fig. 1) and in the latter survey (Kelly and Hester 1975), specific recommendations had been made regarding some of the archaeological resources in the area. It was as a result of these recommendations that the present survey was implemented.

Three archaeological sites, 41 CM 84, 41 CM 85, and 41 CM 86, are situated at the eastern end of the proposed floodwater retarding structure. A11 lie above the 900-foot elevation which represents the margin of the maximum flood pool. However, avallable engineering data suggested that the construction activities involved in the project would lead to the damage or possible destruction of the three sites. Kelly and Hester (1975: 27-29) suggested two possible alternatives regarding the sites: either move the eastern end of the dam so as to avoid the sites entirely, or conduct additional limited investigations so that the sites might be better evaluated. The latter alternative was chosen by the SCS Temple office.

THE SURVEY

An intensive archaeological survey, consisting of a program of controlled surface collection and test pitting, was carried out at sites $41 \mathrm{CM} 84,85$, and 86 (see FIg. 2). These sites, and the other prehistoric resources of Floodwater Retarding Structure Ho. 1, have been previously described in the reports of Hester, Bass and Kelly (1975) and Kelly and Hester (1975). The reader is also referred to those reports for detalls concerning the archaeological background of the region, the local topography, vegetation, and lithic resources.

Field work was administered and supervised by $\mathrm{Dr}$. Thomas $\mathrm{R}$. Hester, Director of the Center. Field operations were under the direction of Thomas C. Kelly, Reseatch Associate of the Center, assisted by Leo C. Fletcher, Francis E. Griffin, Rick Sowa, and two laborers.

Ut1lizing standard archaeological procedures, the field crew accomplished the following tasks: the excavation of two units at $41 \mathrm{CM} 84$, the excavation of another unit at $41 \mathrm{CM} 85$, and a controlled surface collection and the excavation of two untts at $41 \mathrm{CM} 86$. During the 
This page has been

redacted because it

contains restricted

information. 
course of these investigations, yet another archaeological site, $41 \mathrm{CM} 89$, was discovered and documented.

Artffacts, field notes, maps and other data resulting from the survey activities are on file at the Center for Archaeological Research.

\section{TERMINOLOGY}

In the site descriptions that follow, a number of terms are used to refer to the various lithic artifacts collected during the investigations. We provide the following brief definitions of these terns:

cones: nodules of chert or other siliceous stone utilized as a source of raw material (usually in the form of flakes removed from the core).

flakes: pieces of chert detached from a core; the bulk of the flakes in our sample have large striking platforms and pronounced bulbs of percussions, all indicating that direct percussion techniques were used in their removal. There are several major kinds of flakes in the sample. These include primary flakes, representing the initial phases of core shaping and reduction and having the outer faces covered with cortex; secondary flakes exhibit some cortex remnants on the outer face, along with scars indicating previous flake removals; such flakes often indicate the further reduction of cores; interior flakes bear no traces of nodular cortex and thus represent flakes detached from totally decorticated cores; such flakes were apparently selected most frequently for the manufacture of points and other tools; lipped flakes are absent from the present sample; such flakes have distinctive attributes (especially a lenticular, overhanging platform) and are related to the bifacial reduction process; utilized flakes are flakes from any of the above categories which have subsequently been trimmed along the edges (or in some other way modified, as through use-retouch), and which served as casual cutting and scraping implements.

unifaces: in this group of artifacts we have placed specimens (usually thick flakes) modffied on the face. In general, most unffacially flaked tools appear to have served as scrapers. In particular, we noted the presence of unffaces with concave edges, with these edges heavily scarred from use.

bifaces: these are large flakes or chert nodules that have been bifacially flaked. A series of heavy, thick and crudely-flaked bifaces dominate the collections from the sites. Most appear to be quarry blanks, representing an early stage of biface reduction. Some of these may actually be bifaclally-worked cores, while others have battered edges suggestive of use as choppers. The collected sample of quarry blanks includes many fragments of specimens discarded because of materlal flaws or manufacturing failures (such as hinge fractures). 
This page has been

redacted because it

contains restricted

information. 
A later phase in biface production is represented by smaller, thinner bifaces which we refer to as preforms. None were collected during the present investigations, but several were found in the earlier surveys.

hammerstones: ovoid stones of chert, quartzlte, 1 imestone, etc., with battering marks indicative of heavy hammering use, probably in Ithic processing activities.

chunks: miscellaneous blocky chext specimens derived from lithic processing; many are apparently pieces of cores. Others may represent pieces derived from the percussion splintering of lange chert nodules by aboriginal knappers trying to obtain smaller pieces for core or large biface manufacture.

The chipped stone collections from the investigated sites are quite uniform. They apparentiy represent lithic processing activities of the sort associated with prehistoric lithic workshops and quarries (cf. Bryan 1950: Bryan and Tuohy 1960).

\section{RESULTS OF THE INVESTTGATTONS}

Site $41 \mathrm{CM} 84$

This site has been previously described by Kelly and Hester (1975: 15-17). A test pit (Unit A) excavated at the site during the Kelly and Hester survey revealed Iithic materials buried to a depth of $50 \mathrm{~cm}$ below the surface. The recovered artifacts suggest that the site served as a quarry workshop devoted primarily to lithic processing activities. A number of hammerstones, the only ones recovered within the entire project area, were recovered at the site.

In the most recent work at che site, two additional test pits were excavated. Unit $B$ was established 1.2 meters east of the earlier Unit $A$, and Unit $C$ was placed 1.2 meters north of Unit $B$ (see Fig. 2). Both Units $B$ and $C$ were excavated in arbitrary $15 \mathrm{~cm}$ levels to a depth of $45 \mathrm{~cm}$, the point at which bedrock was encountered. The two units yielded 106 primary flakes, 237 secondary flakes, 287 interior flakes, a unifacial scraper, three bifacial artifacts possibly used as choppers, a chert hammerstone, and 34 chunks. Distributional information is presented in Table 1. A series of eight shovel tests around the site periphery revealed shallow deposits with bedrock reached at $15-25 \mathrm{~cm}$ below the surface.

The tabulated flake frequencies (Table 1) indicated the comparitively high percentage of primary and secondary flakes. We believe these data suggest that the predominant function of the site was 1ithic processing, perhaps the reduction of chert cobbles to quarry blanks 
and preforms. The nature of the flakes (large stiling platrorms and pronounced bulbs of percussion) and the presence of 28 hamnerstones in Unit A (Kelly and Hester 1975: 17) provide additional support for this opinion.

The possible chopping tools and concave scrapers found in Unit A (Kelly and Hester 1975: 17) suggest a possible secondary concern with woodworking, perhaps the making of dart shafts. The fact that no dart poincs (or fragments resulting from manufacturing mistakes) were found on the surface or in the excavations indicates that the finishing of lithic artifacts was carried out elsewhere.

\section{Site $41 \mathrm{CM} 85$}

The site is roughly 30 meters in diameter (Figs. 2 and 3). Artifacts collected in the Kelly and Hester (1975) survey were 11 concaveedged unifacial scraping/cutting tools, one steep-bitted unifacial scraper, two heavy bifacial chopping tools, four cleaving/cutting tools and nine flakes. The surface was more visible in September 1975, because of engineering activity in the structure right-ofway and the deterioration of the dense underbrush due to seasonal variation and cattle grazing. More chert raw material and artifacts were exposed than were collected in the "total" sampling obtained in Apri1, 1975.

A two-meter square test pit was established and excavated in $15 \mathrm{~cm}$ arbitrary levels. Nothing was found below $25 \mathrm{~cm}$ (a sterile dark brown clay was observed at this depth). The recovered specimens were 159 primary flakes, 311 secondary flakes, 138 interior flakes, 28 utilized flakes, two bifacial chopping tools, four concave-edged unifacial scrapers, one bifacial quarry blank, and two heavy flake scrapers (Table $1 ; \mathrm{Fig}, 5, f, i)$. The utilized flakes have edges modified through heavy use; they are generally cortex-backed, or were selected with a natural flat backing surface opposite the utilized edge. From an examination of Table 3 , it is noted that the percentage of primary and secondary flakes is large in comparison to the interior flakes, and in relation to flake counts of selected other sites. The nature of the flake assemblage, makeup of the tool kit, and the complete absence of dart points or fragments or other habitational evidence, is again interpreted as indicating a site specializing in the conversion of chert (and possibly wood) to a semi-finished state for final completion elsewhere.

Despite the fact that al1 artifacts recovered were made by hammerstone percussion (the flakes exhibit large unprepared striking platforms and massive bulbs of percussion), no hammerstones were recovered from the site. 


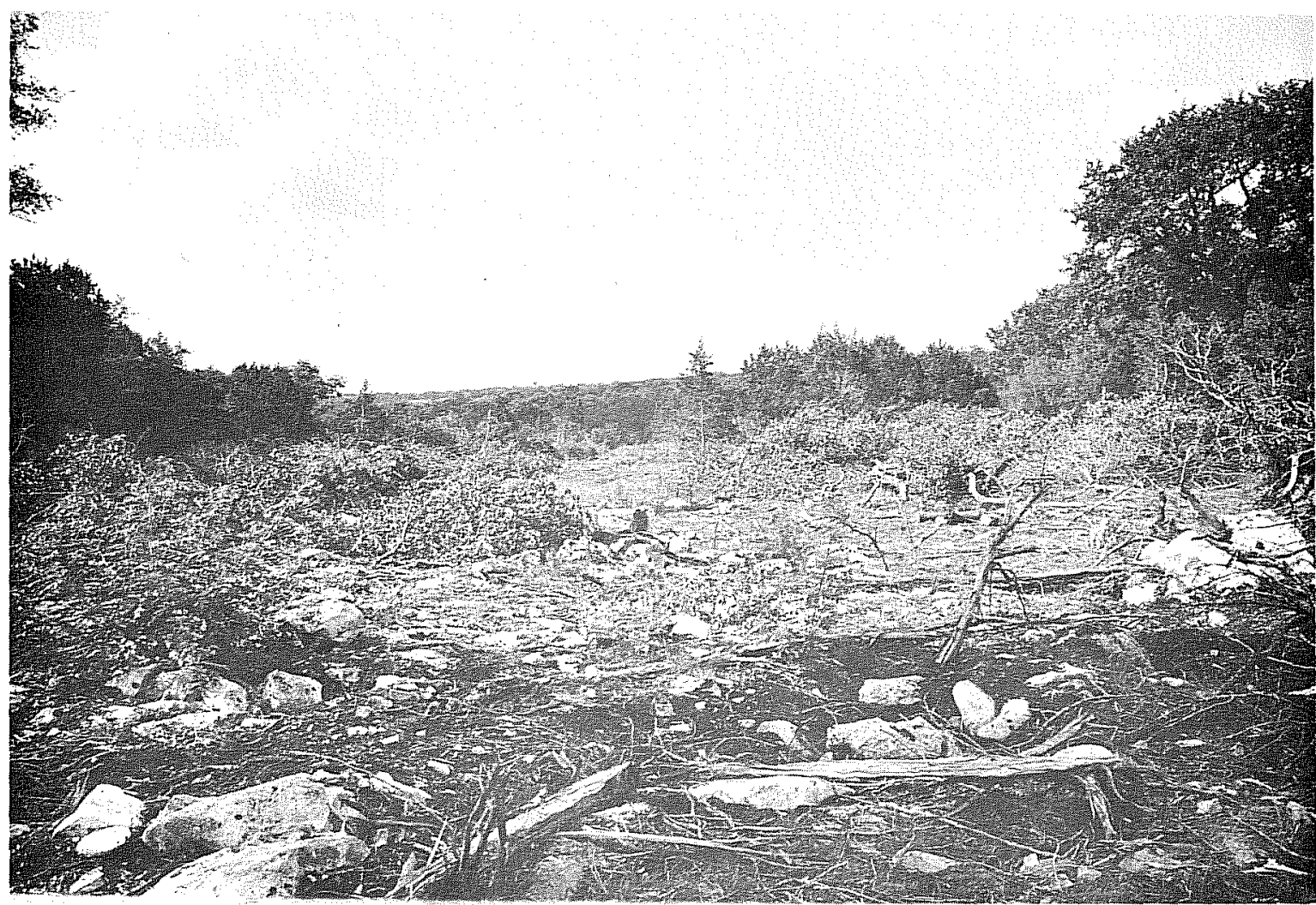

a

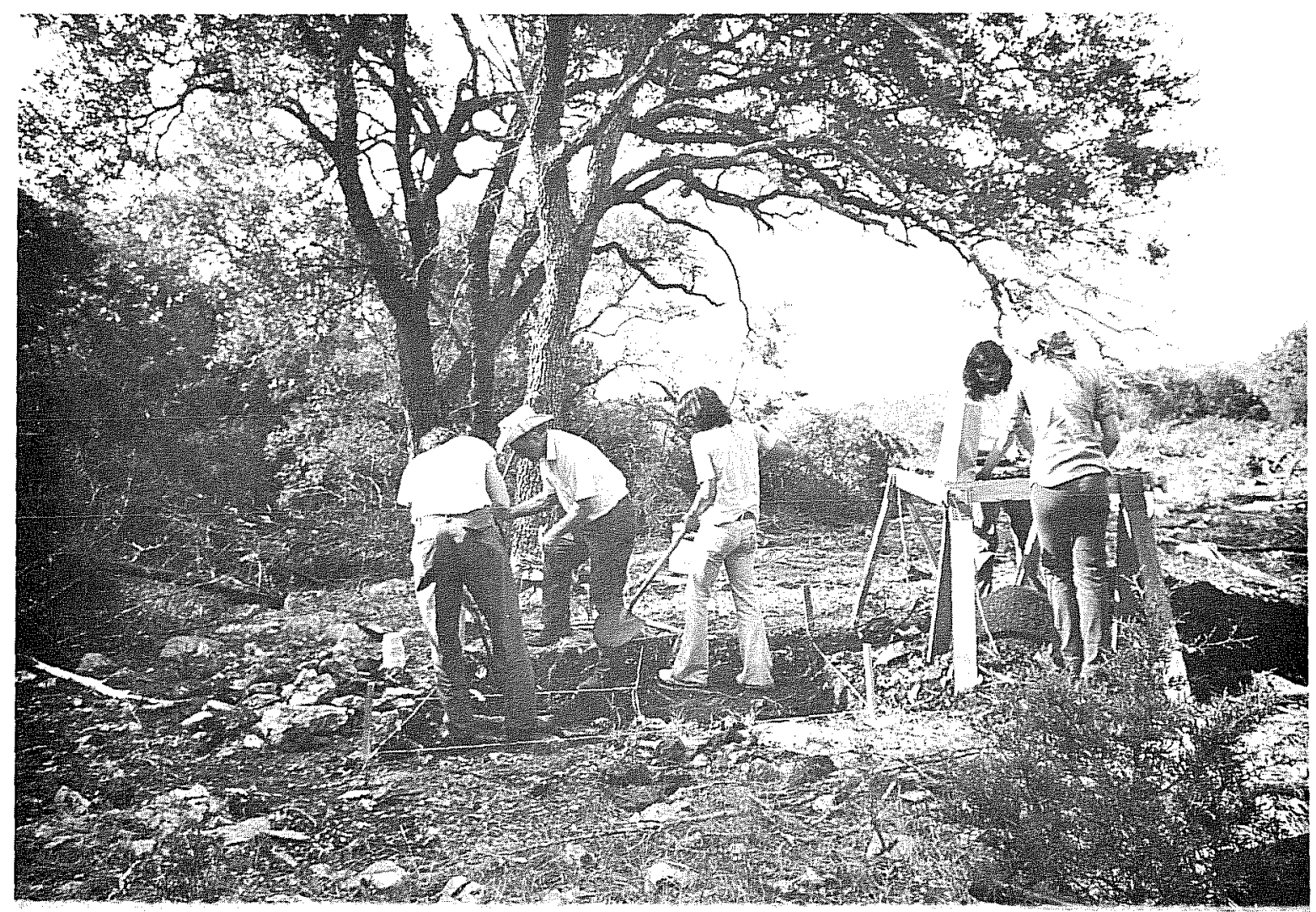

b

Figure 3. Views of Site $41 \mathrm{CM}$ 85. a, general view along cleared dam site; $b$, excavation of test pit. 


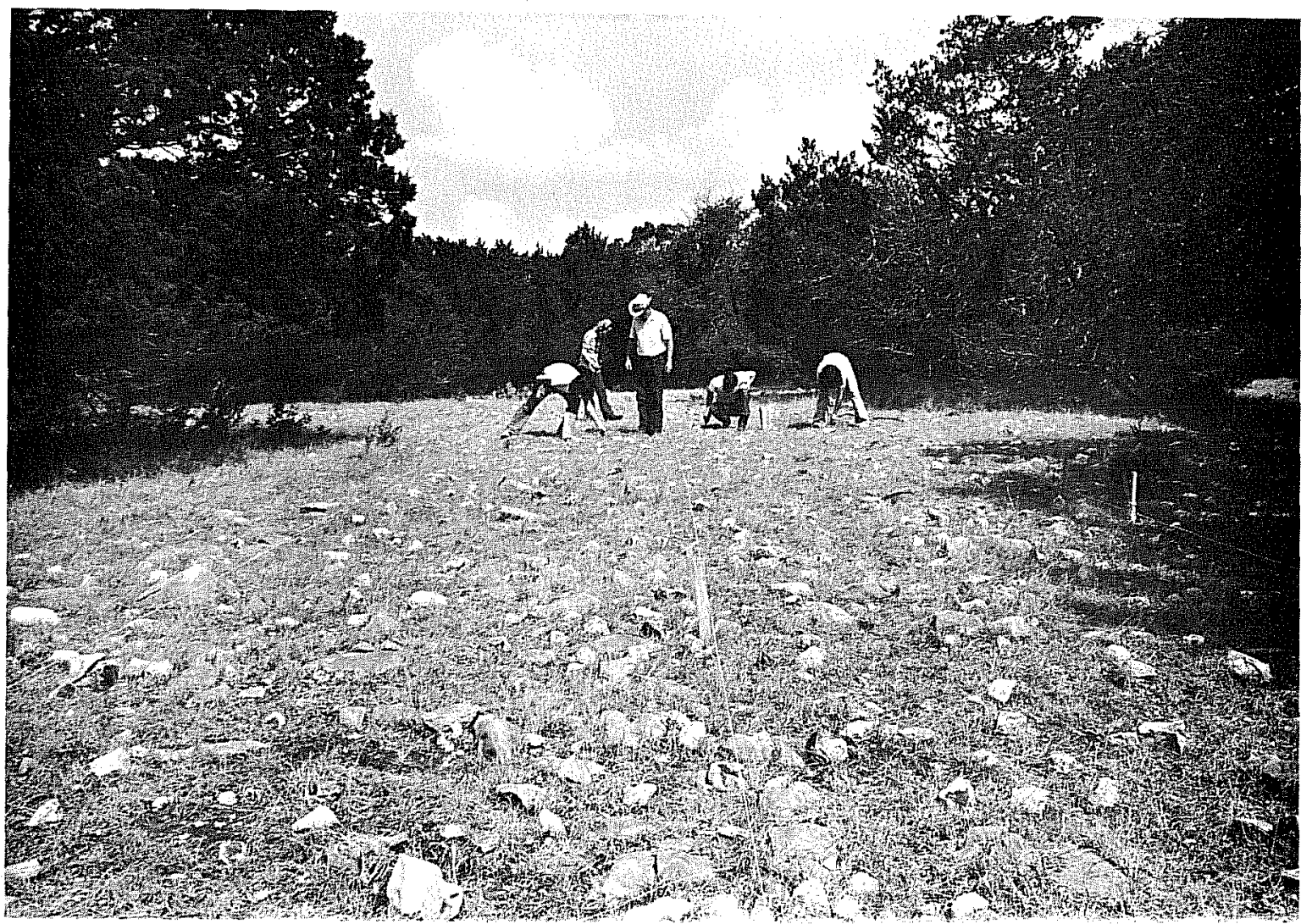

a

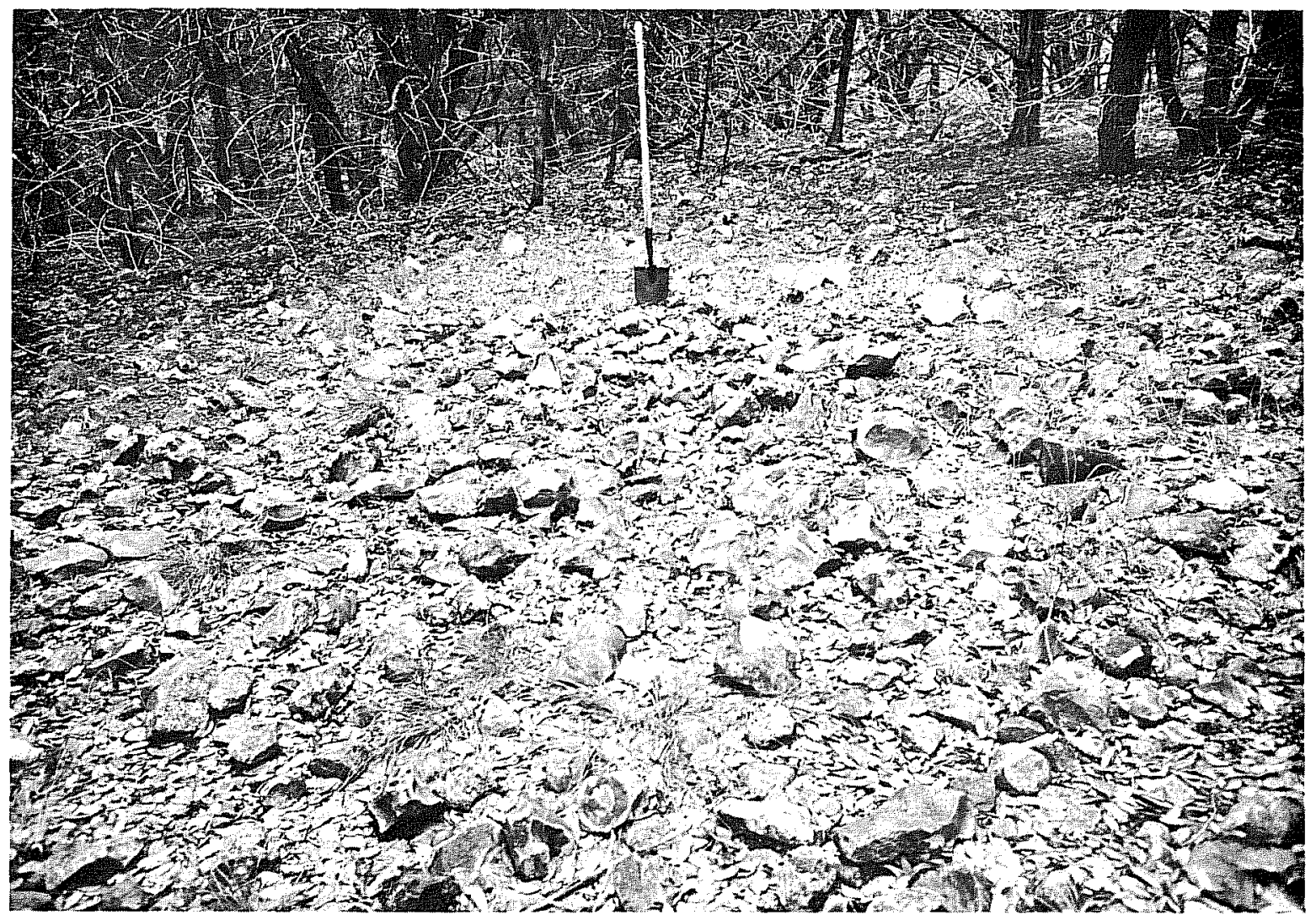

b

Figure 4. Views of Sites $41 \mathrm{CM} 86$ and $41 \mathrm{CM}$ 89. a, controlled surface collecting in progress at $41 \mathrm{CM} 86 ; \mathrm{b}$, view of quarry debris on the surface at $41 \mathrm{CM} 89$. 


\section{$41 \mathrm{CM} 86$}

This site is oval in plan, oriented from north to southeast, and is approximately 15 meters wide and 60 meters in length (Fig. 4, a). This site was gridded for controlled surface collection, utilizing as a datum a steel peg in the centerline of the dam at the end of the proposed structure. A series of nine collecting units, 6.0 by 2.5 meters in size, was established (see Fig. 2), and were labeled, in sequence, as Units $A-H$, with right and left divisions. In this fashion, a block 48 meters long and 5 meters wide was collected. Every piece of modified material within each unit was bagged. As a test to determine the depth of cultural material, two 1 by 1 meter units were excavated after the controlled collecting had been completed (one within the E-left collection unit, and one within G-left). Using $15 \mathrm{~cm}$ arbitrary levels, the units were dug to a depth of $22 \mathrm{~cm}$, where bedrock was encountered. Cultural materials were found to be mainly surficial.

The collected artifacts included three bifacial quarry blanks, 39 unifaces (22 concave-edged unifacial scrapers and 17 rake scrapers), six heavy bifaces (cores or choppers), 112 utilized flakes, 250 primary flakes, 452 secondary flakes, and 269 interior flakes (see Table 2 and Fig. 5, a-c, g, h) 。

In Table 3, the high percentages of primary and secondary flakes are noted. When one compares the data from $41 \mathrm{CM} 36$ with such multiactivity sites as La Jita (Hester 1971), $41 \mathrm{HY} 72$ (Patterson 1974), and $41 \mathrm{KE} 49$ ( $\mathrm{Kelly}$ and Hester $\mathrm{ms}$. ), the high percentage of primary flakes suggests that the function of $41 \mathrm{CM} 86$ was that of lithic processing, presumably the early phases of core and biface production.

The April survey (Relly and Hester 1975) of this site yielded only large, heavy cores and core tools. These included one chopper/ scraper, three cutting/chopping tools with concave edges, three quarry blanks, and five cleaver-1ike cutting or chopping tools. No projectile points, point Eragnents, hammerstones, burned rocks, etc. were found in either survey.

The site is interpreted as being a specialized site for converting chert cobbles to quarry blanks and preforms. The limited tool kit (scraping, cutting, and chopping tools) may reflect woodworking tasks, such as the cutting, trimming, and smoothing of wood for dart shafts or other objects.

The excavation of the two 1 by 1 meter test pits revealed that there were fewer buried flakes and artifacts than on the surface, indicating that considerable deflation has taken place.

Site 41 CM 89

This is an important site not found in either of the other two surveys, despite 1ts proximity to $41 \mathrm{CM} 84$. The site (Fig. 4, b) is located in and 
alongside a gully or ravine, with three major branches. The three branches originate as shallow depressions a few meters southwest of the Krause stone boundary fence (FIgs. 1, 2), and deepen abruptly as they proceed southwest toward the wain channel of the ravine. The large ravine terminated in the alluvial flats before reaching the creek channe1; but the site debris ends approrimately 20 meters below the branch intersections. Dense cedar thickets dominate the area; other vegetation congists of live oak, persimnon, agarita, sparse grass, and weeds. There are four fairly open areas on the flats above the ravine branches (Fig. 2).

A limited sample of artifacts was collected, and selected specimens are illustrated in Fig. 6. Artifacts collected from, or observed at, the site consist of the following forms: bifacial quarry blanks (some of these seem to have chopper-like wear along the edges), large cores and core fragments, and numerous large flakes (some of the flakes exhibit what appears to be wear derived from chopping and scraping function). The site contains great quantities of chert cobbles, many of them "tested" by the removal of one or more flakes, as well as numerous artifacts, debitage, and unaltered chert cobbles. Over the millenia, the ravine has cut through limestone and released the chert nodules, creating a major quarry site for the survey area.

\section{OBSERVATIONS ON THE LITHICS FROM THE SITES}

All four sites contain lithic debris primarily attributable to workshop operations. Two aspects of the site assemblages were of particular interest to us, and we provide some brief comments on these in this section of the report.

At $41 \mathrm{CM} \mathrm{84,} \mathrm{we} \mathrm{noted} \mathrm{a} \mathrm{considerable} \mathrm{concentration} \mathrm{of} \mathrm{hammerstones.}$ Their presence was even more remarkable in light of the absence of hammerstones at other sites in the project area. Bordaz (1970: 56) has commented on the scarcity of hammerstones in many ancient archaeological sites. He put forth the theory that flint-knappers were usually specialists, and that good hammerstones would be carefully preserved in their personal tool kits. Thus, hammerstones would not be left behind the quarry sites, but would be taken by the knappers whenever the group moved away from a particular locality. In briefly checking some of the literature on south central Texas sites, we note that hamerstones are quite rare at most of them. In neighboring Hays County, a site survey of far greater scope turned up only three hammerstones (Patterson 1974: 33). As another example, Hester (1971) found only one specimen in the La Jita occupation site in Uvalde County.

Why, then, do we find this concentration of hammerstones in a small knapping site like $41 \mathrm{CM} 84$ ? All of the hammerstones are of poor quality chert (referred to as "siliceous limestone" in Kelly and Hester 1975: 7). This material is rare among the flakes and debris at the site, and it does not appear that hammerstones were being shaped or 

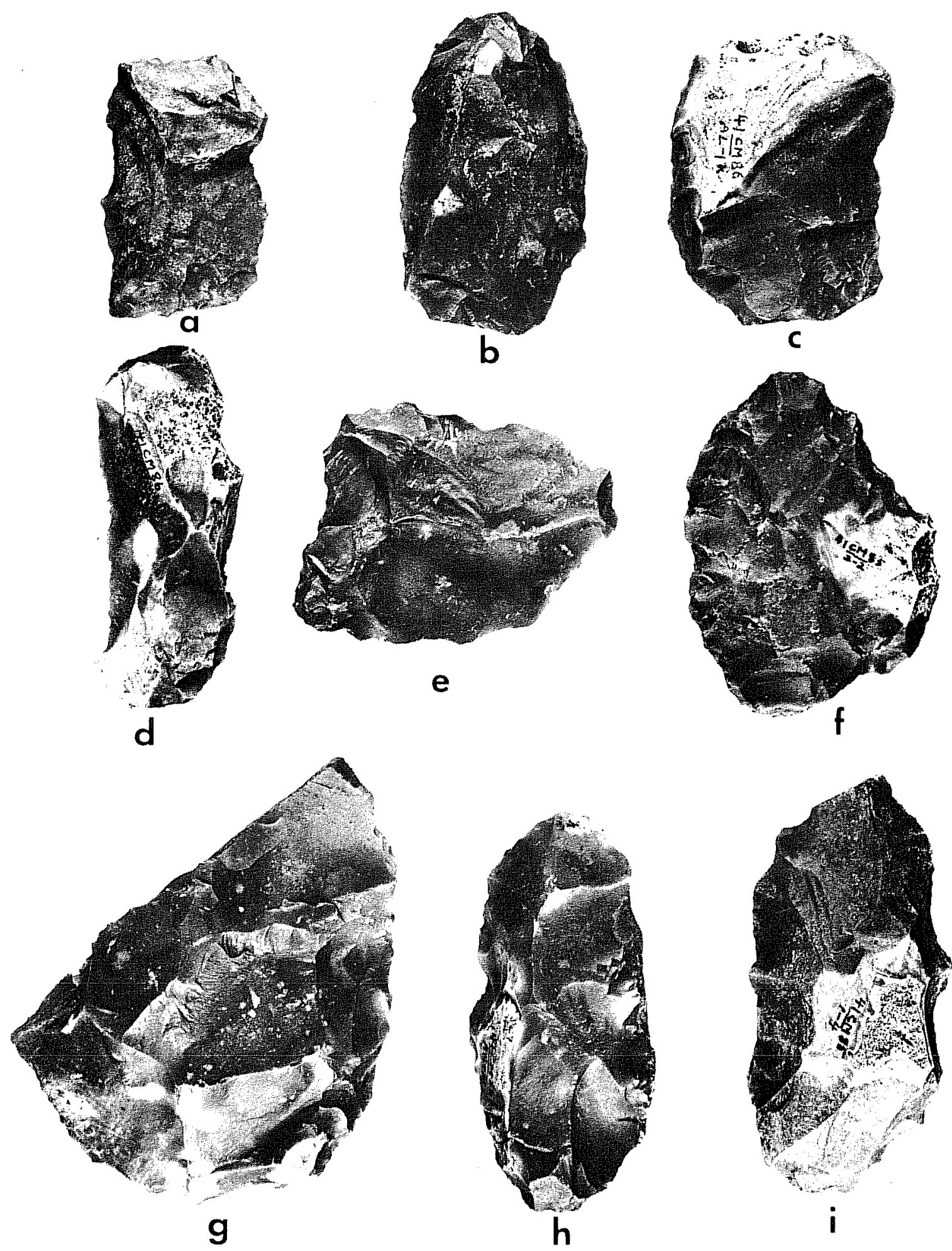

$$
\mathrm{cm}\left|\begin{array}{l|l|l|l|l|l}
1 & 1 & 1 & 1 & 1 & 1 \\
1 & 2 & 3 & 4
\end{array}\right|
$$

Figure 5. Lithics from Sites $41 \mathrm{CM} 85$ and $41 \mathrm{CM} 86$. a-c utilized flakes (41 CM 86); d, e, flakes (41 CM 86); f-i, quarry blanks (f, $i, 41$ CM 85; $\mathrm{g}, \mathrm{h}, 41 \mathrm{CM} 86)$. 

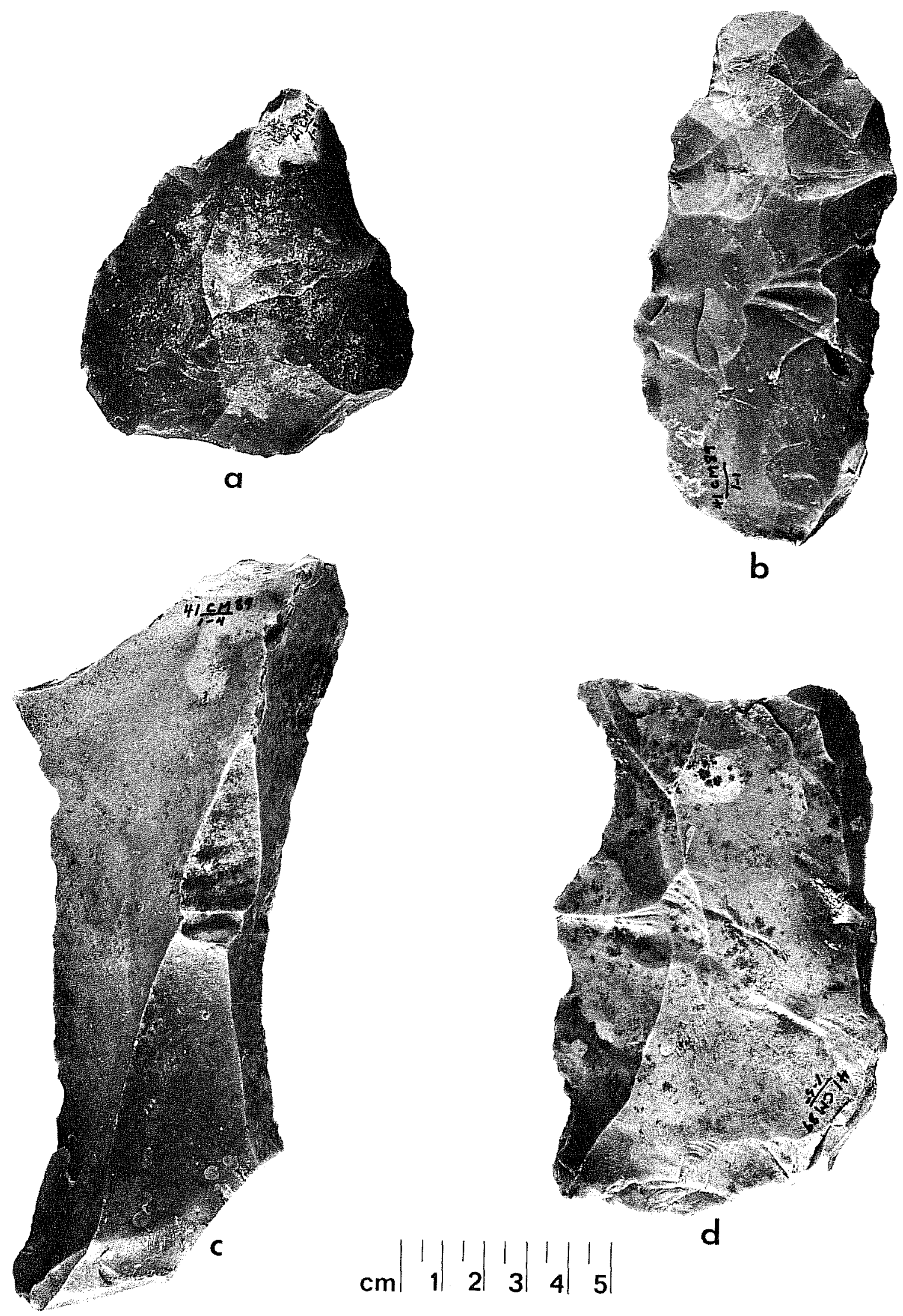

Figure 6. Lithics from Site $41 \mathrm{CM}$ 89. a, utilized flake; b, quarry blank; $c, d$, flakes. 
manufactured at the site. Perhaps this concentration of hammerstones represents the caching of knapping tools at a workshop site situated near a virtually unlimited supply of raw material, $41 \mathrm{CM} 89$. We suspect that the primary activity at $41 \mathrm{CM} 84$ was the production of quarry blanks which were subsequently transported to other sites*.

A second, and considerably more significant, aspect of the lithic assemblage involved a comparison of flake frequencles at these sites with other published debris studies in the regional ilterature. It was felt that such a comparison would help to test the proposition that these sites were indeed lithic processing areas.

Thus, the flake counts obtained from $41 \mathrm{CM} 84,41 \mathrm{CM} 85$, and $41 \mathrm{CM}$ 86, were compared to such sites as Jetca Court (Weslowsky, Hester and Brown 1976), La Jita (Hester 1971), 41 HY 72 (Patterson 1974) and $41 \mathrm{KE} 49$ (Ke11y and Hester ms.). Three najor categories of flakes -- prinary, secondary, and intertor -- were utilized in these comparisons. Results are shown in Table 3. The three Comal County sites are obviously similar to one another in terms of the kinds and frequenctes of flakes. Their highly specialized nature is indicated by the unusually heavy concentrations of primary flakes (from $17 \%$ to $33 \%$; mean, 23\%). At these sites, it would appear that chert nodules were being obtained from nearby surface exposures, and were being reduced via hammerstone percussion to forms such as quarry blanks and preforms. We believe that the blanks and preforms were taken elsewhere, probably to occupation sites (1ike $41 \mathrm{CM} 88$; see Kelly and Hester 1975: 22, 25) For final conversion into finished artifacts.

In these sites, we see a combined primary and secondary flake irequency of $55 \%$ to $75 \%$. OnIy at one other site, 41 HY 72 (Patterson 1974) with a combined total of $47 \%$, are these percentages even approached. Patterson defines this site as a lithic tool manufacturing site in a "lithic resource procurement area." Preforms, cobbles, and cores made up the bulk of other artifacts, along with five bifaces and one dart point fragment. The probable woodworking tools of the Dry Comal workshops are absent. Patterson reports that 41 HY 72 contained tabular chert as well as cobbles. This could account for the small percentage of primary flakes (3\%) compared with the Dry Comal mean of $23 \%$.

Distinctively different patterns of flake frequencies are present at occupation sites like La Jita, Jetta Court, and $41 \mathrm{KE} 49$. La Jita Area C compares rather closely with the composite picture of $41 \mathrm{KE} 49$.

*In the senior author ${ }^{\circ} \mathrm{s}$ experiments in flint-knapping, he has found that two hammerstones are necessary in reducing cobbles to quarry blanks. A large hammerstone is required to renove irregularities from the nodule and to create a series of working areas or platforms. A smaller hammerstone is then used in removing the cortex and in the shaping of the blank. If the work were to be carried to the preform stage, he suggests that a third, yet smaller, hammerstone would be desirable. 
The combined primary and secondary flake percentages are $31 \%$ and $30 \%$ respectively, with interior flake percentages of $69 \%$ and $70 \%$. Hester (1971) defines La Jita area $C$ as a Middle Archaic terrace occupation where all steps in the manufacturing of stone tools took place. $41 \mathrm{KE} 49$ is the same type of site apparently dating from the Early and Pre-Archaic periods.

La Jita Area $F$ has an unusual pattern as it contains no primary flakes. Hester describes it as a buxned rock midden containing little in the way of lithic debris. Ia Jita Area A and all units at Jetta Court are nearly identical in flake percentages. Their low primery flake percentages ( $1 \%$ and $2 \%$ ) indicate that the processing of cores, quarry blanks and preforms was done elsewhere: finished manufacture of artifacts occurred in the camping area.

\section{SUMMARY AND RECOMMENDATIONS}

The present report describes the results of the third in a series of archaeological studies in the area of Floodwater Retarding Structure No. 1, Dry Comal Creek Watershed, south central Texas. As a result of the survey activities, total of 25 archaeological sites has been identified and documented. All but one of the sites appear to be linked to lithic processing activities, notably the extraction (or selection) of chert raw material, and the working of this material into cores, flakes, and crude bifaces and unifaces*. Four distinct groups of chert were utilized by the prehistoric knappers; in Kelly and Hester (1975: 6) the distribution of cherts among the sites was presented.

The report of Kelly and Hester (1975) contained specific recommendations regarding sites $41 \mathrm{CM} 84,41 \mathrm{CM} 85$, and $41 \mathrm{CM} 86$. Although the authors preferred the alteration of project plans so that the sites would be preserved, it was determined by SCS officials that this would probably not be possible at this late date in the planning process. Thus, an intensive survey was to obtain additional information on the sites, so that final recommendations could be made. A survey team was sent into the field to obtain such information as precise site location and site size, to collect additional surface samples for evaluation, and to carry out Iimited test pitting to ascertain the presence or absence of significant buxied deposits. It was intended that these data would be used to prepare comprehensive evaluations of the sites and to measure their importance in term of possible nomination to the National Register of Historic Places.

At site $41 \mathrm{CM} 84$, test pitting revealed deposits up to a maximum depth of $45-50 \mathrm{~cm}$; much of the site, however, is only $15-25 \mathrm{~cm}$ thick. The

The one site not attributable to chert-working tasks is $41 \mathrm{CM} 88$, a large occupation site located just outside the project area. 
unstratifled deposits contained lithic debris related to workshop activities. Analysis of recovered materials indicated that lithic processing was an obvious function of the site; a secondary function may have been woodworking (or some simllar task), as suggested by the occurrence of concave-edged unifacial scraping implements.

The field crew excavated a single test pit at site 41 CM 85 . Shallow

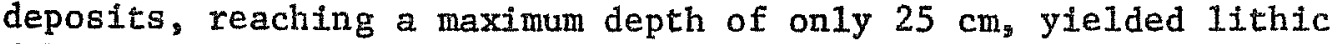
debris also attributable to lithic processing and possible woodworking activities.

Controlled surface sampling was the major investigative technique employed at site $41 \mathrm{CM}$ 86. Again, an assemblage of artifacts related to workshop activities was recovered. Test pits indicated shallow deposits with buried lithics being thinly scattered.

During the course of these field studies, site $41 \mathrm{CM} 89$ was dism covered. Brief examination of the site suggested that it is a major lithic processing locality, and may be the source of much of the chert, especially type B of Kelly and Hester (1975) used at workshops in the area. We cannot ascertain to what extent this site might be modified by the construction of the floodwater retarding structure. At least the lower parts of the gully (roughly 25\% of the site area) will lie below the 900-foot elevation and will thus be incorporated into the project.

We belleve that the combined field work of the Kelly and Hester (1975) survey and the studies reported here have provided an appropriate sample of materials from sites $41 \mathrm{CM} 84,41 \mathrm{CM} 85$ and $41 \mathrm{CM} 86$. The three sites seem to have had similar functions; all are fairly small, with shallow deposits of limited potential. It is likely that

41 CM 84 will be partially damaged during construction activities; 41 CM 85 and 41 CM 86 will probably be partially or totally destroyed. As we stated in our earlier report (Kelly and Hester 1975: 29), we consider all archaeological resources to be of value. However, given the nature of these three sites, we believe we have gained a thorough knowledge of their composition and function. We seriously doubt that further, more extensive field research would provide much in the way of significant archaeological information. The loss, or partial loss, of these three sites would not deter future research in stites of this function in the immediate area, as we have already documented nearly 20 sites of similar character in the project locality. Indeed, most of these other sites appear to us to have a much greater potential to yield information on the lithic processing and possible woodworking activities that were conducted at these specialized sttes. Fortunately, the construction of Floodwater Retarding Structure No. 1 will not affect, as best we can determine, these other archaeological resources. After consultation with personnel of the Texas Historical Commission regarding our findings and evaluations, we are of the opinion that sites 41 CM 84 s 85 and 86 should not be nominated to the National Register of Historic P1aces. 
We come now to the status of site $41 \mathrm{CM} 89$. Perhaps as much as $75 \%$ of this site lies outside the project area. However, our initial inspection strongly suggests that this is a site of major importance in terms of future inquiries Into prehistoric chert-working processes in south central Texas. It may be that the portion of the site extending into the project area will not be affected by either the construction phase or the subsequent short term impoundment of waters behind the floodwater retarding structure. We belleve that 41 CM 89 is a highly significant resource, and one which warrants its nomination to the National Register of Historic Places. We urge the Soil Conservation Service to inspect the site area and to determine its exact position and elevation. It should be carefully evaluated in terms of its relationship to the construction of the floodwater retarding structure. If there is a possibility that $41 \mathrm{CM} 89$ will be affected or modified in some way, we strongly urge further research at the site. 
ADDENDUM

The recommendations contained in the preceding section of this report were made available to the Soil Conservation Service state office (Temple, Texas) in early December, 1975.

In a letter dated December 31, 1975, Mr. Logan W. Crews, Assistant State Conservationist, summarized the course of action proposed by the SCS at these sites during the construction phase at Floodwater Retarding Structure No. 1:

"1. Site $41 \mathrm{CM} 84$ is above the detention pool but near the dam. We plan to flag it during construction. It is not considered eligible for nomination to the National Register of Historic Places.

2. Site $41 \mathrm{CM} 85$ is located at the north end of the dam on the centerline and will be disturbed by construction. It is not considered eligible for nomination to the National Register of Historic Places.

3. Site $41 \mathrm{CM} 86$ is located above the north end of the dam. We plan to flag it during construction. It is not considered eligible for nomination to the National Register of Historic Places.

4. Site $41 \mathrm{CM} 89$ is barely above the detention pool and near enough to the dam to merit protection. It wiIl be flagged and monitored during construction. It is considered eligible for nomination to the National Register of Historic Places and we would urge UTSA to initiate its" nomination if it has not already been done."

According to James Warren (SCS archaeologist), the flagging of sites $41 \mathrm{CM} 84$ and 86 will minimize the impact resulting from construction.

As stated elsewhere in the report, we believe that the disturbance and/or partial destruction of sites 41 CM 84, 85, and 86 will not adversely affect the local archaeological picture; further, such disturbance will have been preceded by intensive archaeological study. We are grateful to the Soll Conservation Service for their cooperation in all phases of our investigation in the area of Floodwater Retarding Structure No. 1. Their concern for the protection and preservation of archaeological resources is a serious one, and should serve as an example for similar agencies in other states. 
TABLE 1

\section{CM 84, 41 CM 85: Excavated Collections}

$41 \mathrm{CM} 84$

\begin{tabular}{|c|c|c|c|c|c|c|c|c|c|}
\hline \multirow{3}{*}{ UNIT B } & 1 & 22 & 53 & 61 & $I$ & 2 & - & -- & 139 \\
\hline & 2 & 42 & 43 & 52 & - & - & - & - & 137 \\
\hline & 3 & -- & 2 & 1 & - & - & - & 26 & 29 \\
\hline \multirow[t]{3}{*}{ UNIT C } & 1. & 12 & 39 & 45 & - & - & - & 8 & 104 \\
\hline & 2 & 30 & 82 & 105 & - & 1 & 1 & -- & 219 \\
\hline & 3 & -- & 18 & 23 & - & - & - & - & 41 \\
\hline \multicolumn{2}{|l|}{ TOTAL } & 106 & 237 & 287 & 1 & 3 & 1 & 34 & 669 \\
\hline$\%$ & & 15. & 35. & 42.8 & .02 & .04 & .02 & 5.1 & $100 \%$ \\
\hline
\end{tabular}

$41 \mathrm{CM} 85$

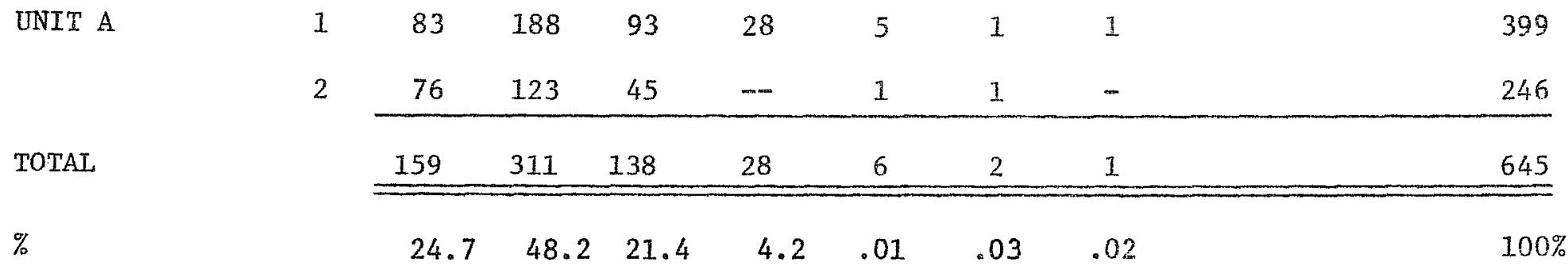




\section{TABLE 2}

41 CM 86 Controlled Surface Collection

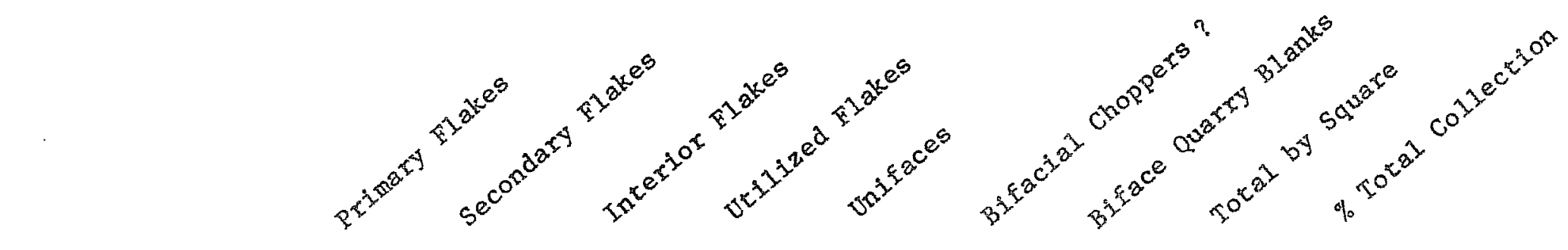

\begin{tabular}{|c|c|c|c|c|c|c|c|c|c|c|}
\hline A & LEFT & 19 & 35 & 27 & 11 & 7 & - & 1 & 100 & 8.8 \\
\hline$B$ & $" 1$ & 6 & 18 & 8 & 3 & - & 3 & - & 38 & 3.4 \\
\hline $\mathrm{C}$ & 88 & 0 & 16 & 13 & 3 & 1 & - & - & 33 & 2.9 \\
\hline$D$ & 18 & 5 & 17 & 7 & 6 & 2 & 1 & - & 38 & 3.4 \\
\hline$E^{*}$ & $"$ & 84 & 40 & 23 & - & 1 & - & - & 148 & 13.0 \\
\hline $\mathrm{E}$ & " & 5 & 15 & 9 & 5 & 2 & - & - & 36 & 3.2 \\
\hline$G$ & $"$ & 14 & 30 & 16 & - & 2 & - & - & 62 & 5.5 \\
\hline$G^{*}$ & Pr & 28 & 16 & 11 & - & 1 & - & - & 56 & 5.0 \\
\hline H & "1 & 12 & 35 & 23 & 14 & 1 & - & 1 & 86 & 7.6 \\
\hline TOT & $n$ & 173 & 22 & 137 & 42 & 17 & 4 & 2 & 597 & 52.8 \\
\hline
\end{tabular}

\begin{tabular}{|c|c|c|c|c|c|c|c|c|c|c|}
\hline A & RIGHT & 1.3 & 21 & 17 & 17 & 3 & 1 & 1 & 73 & 6.5 \\
\hline$B$ & $n$ & 4 & 17 & 4 & 2 & 2 & 1 & - & 30 & 2.6 \\
\hline $\mathrm{C}$ & 11 & 13 & 28 & 16 & 6 & 4 & - & - & 67 & 5.9 \\
\hline $\mathrm{D}$ & 11 & 9 & 18 & 13 & - & - & $-\infty$ & $\infty$ & 40 & 3.5 \\
\hline$E$ & $" 1$ & 11 & 17 & 4 & - & 1 & - & - & 33 & 2.9 \\
\hline$F$ & $m$ & 0 & 28 & 7 & 10 & 2 & - & - & 47 & 4.3 \\
\hline$G$ & 11 & 4 & 16 & 12 & 9 & 1 & - & - & 42 & 3.7 \\
\hline$\ddot{H}$ & is & 23 & 85 & 59 & 26 & 9 & - & - & 202 & 17.8 \\
\hline & "1 & 77 & 230 & 132 & 70 & 22 & 2 & 1 & 534 & 47.2 \\
\hline
\end{tabular}

\begin{tabular}{|c|c|c|c|c|c|c|c|c|c|}
\hline GRAND TOTAL & 250 & 452 & 269 & 112 & 39 & 6 & 3 & 1131 & $100 \%$ \\
\hline$\%$ of TOTAL & 22.1 & 40 & 23.8 & 10 & 3.5 & .5 & .3 & 100 & \\
\hline
\end{tabular}

* Includes 1 Meter Excavated Square 
TABLE 3

Comparisons of Flake Categories at Several South-Central and Central Texas Sites

\section{0}

90

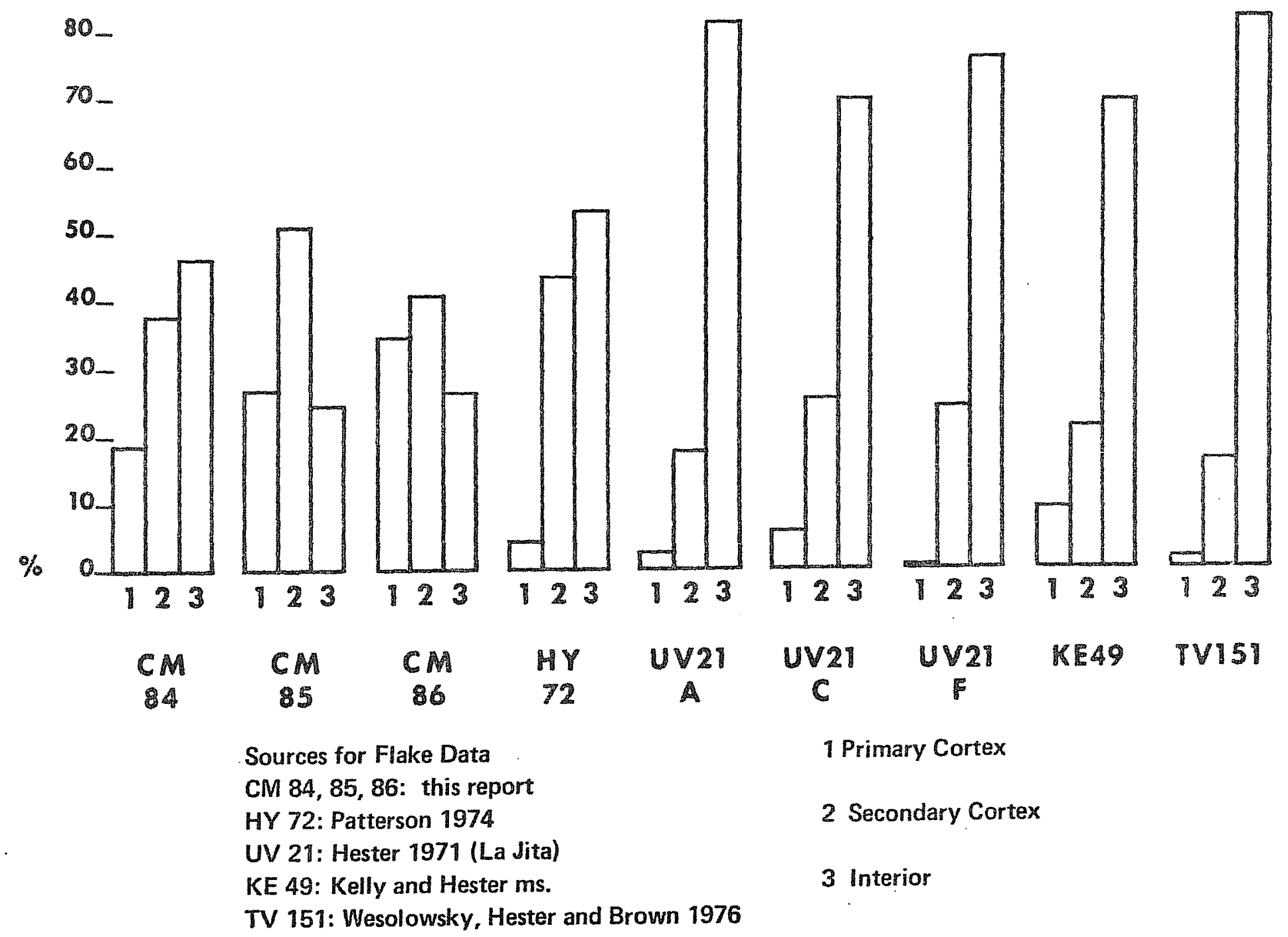




\section{REFERENCES CITED}

Bryan, $\mathrm{K}$.

1950 Flint Quarries: the sources of tools, and at the same time, the factories of the American Indians. Papers, Peabody Museum of American Archaeology and Ethnology 17 (3).

Bryan, A. L. and D. R. Tuohy

1960 A Basalt Quarry in Northeastern Oregon. Proceedings, American Philosophical Society 104: 485-510.

Bordaz, J.

1968 Tools of the Oed and New Stone Age. Natural H1story Press, Garden City, N. J.

Hester, T. R.

1971 Archeological Investigations at the La Jita Site, Uvalde County, Texas. Bulletin of the Texas Archeological Society 42: 51-148.

Hester, T. R., F. A. Bass, Jr, and T. C. Kelly

1975 Archaeological Survey of Portions of the Comal River Watershed, Comal County, Texas. Center for Archaeological Research. The University of Texas at San Antonio, Archaeological Survey Report 6.

Ke11y, T, C. and T, $R$. Hester

1975 Additional Archaeological Survey in the Dry Comal Watershed, Comal County, South Central Texas. Center for Archaeological Research. The University of Texas at San Antonio. Archaeological Survey Repont 10.

Ke11y, T. C. and T. R. Hester

1975 Archaeological Investigations in the Upper Cibolo Watershed, Kendal1 County, Texas. Center for Archaeological Research. The University of Texas at San Antonio, Archaeological Survey Report 17 (in preparation). 
Patterson, P. E.

1974 Upper San Marcos River Watershed, Hays County, Texas: An Archeological Survey of Areas Proposed for Modification. Texas Archeological Survey. The University of Texas at Austin. Research Repont 42.

Wesolowsky, A. B., T. R. Hester and D. Brown

1976 Archeological Investigations at the Jetta Court Site, 41 TV 151. Travie County, Texas. Bulletin of the Texas Archeological Society 47 (in press). 